Original Research

\title{
Strategi Pengembangan Komoditas Unggulan di Kelurahan Banturung Kecamatan Bukit Batu Kota Palangka Raya
}

\author{
Andreas Jongguran Sihombing ${ }^{1,2,{ }^{*}}$, Evi Feronika Elbaar ${ }^{2,3}$, Soaloon Sinaga ${ }^{2,3}$ \\ ${ }^{1}$ Dinas Pertanian dan Ketahanan Pangan Kota Palangka Raya \\ 2 Program Studi Magister Pengelolaan Sumberdaya Alam dan Lingkungan Program Pascasarjana Universitas Palangka Raya \\ ${ }^{3}$ Fakultas Pertanian Universitas Palangka Raya \\ * Korespondensi: Andreas Jongguran Sihombing (Email: andresihombing21@gmail.com)
}

\begin{abstract}
Banturung village, located in Bukit Batu Subdistrict, Palangka Raya city, is known with its considerable agricultural products, especially in horticultural crops subsector. The superior horticultural crops commodities, however, needs more attention since input side of production process is still experiencing problems for further development. Hence formulating strategy for its development is a nessecity. This study aims to identify leading commodities and to formulate development strategy for such commodity in the village. A LQ analysis and farmers' preferences were used to determine the superior crops, while SWOT analysis was applied to formulete development strategy for the superior one. The results showed top four commodity were beans $(L Q=8.26)$, long beans $(L Q=2.75)$, onions red $(L Q=2.06)$, and eggplant ( $L Q=1.84$ ). The strategies could be took for their development are: 1) increasing cooperation/ partnership between farmer institutions and private or government parties, 2) increasing the carrying capacity of infrastructure and facilities, 3) optimizing capital assistance from government as stimulant for processing innovation, marketing, and dissemination of products, and 4) providing information and data to support marketing inquiry.
\end{abstract}

\section{Keywords}

Strategy, development, superior commodities

\section{PENDAHULUAN}

Pemerintah daerah Kota Palangka Raya merupakan salah satu daerah yang mengupayakan pengembangan kawasan perdesaan berbasis agroindustri. Penetapan kawasan tersebut ditetapkan pada Peraturan Daerah Kota Palangka Raya Nomor 07 Tahun 2001 tentang Rencana Tata Ruang Wilayah Kota Palangka Raya. Sasaran dari dari Rencana Tata Ruang Wilayah Kota Palangka Raya pada pasal 32 poin b ditetapkan wilayah pengembangan II (Utara Kota Palangka Raya) yang berfungsi sebagai sub regional serta pariwisata, perdagangan, perhubungan, telekomunikasi dan pemukiman, serta kawasan agroindustri.

Salah satu wilayah yang ditetapkan sebagai pengembangan kawasan berbasis agroindustri adalah Kelurahan Banturung Kecamatan Bukit Batu yang berfungsi sebagai pusat pelayanan lokal, perkebunan, perikanan, kehutanan, dan pertanian. Topografi dataran dan iklim Kelurahan Banturung yang agak basah memungkinkan untuk dikembangkan berbagai komoditas pertanian, seperti tanaman pangan, holtikultura, peternakan, perikanan, dan perkebunan yang berbasis pada agribisnis. Hal ini didukung oleh Surat Keputusan Walikota Palangka Raya. Berdasarkan Surat Keputusan Walikota Palangka Raya No 188.45/510/2015 tentang penetapan lokasi tanah kepada Dinas Pertanian, Perkebunan, Pelaksana Penyuluhan untuk kepentingan pembangunan Taman Teknologi Pertanian (Agro Technopark) dimana telah diputuskan bahwa TTP berada di Kelurahan Banturung Kecamatan Bukit Batu.

Kelurahan Banturung terletak di Kecamatan Bukit Batu, Kota Palangka Raya dengan jumlah penduduk 5075 jiwa (BPS, 2018). Sumber pendapatan masyarakat sekitar secara keseluruhan dengan mamanfaatkan potensi wilayah 
tersebut dengan bertani. Hal ini didukung oleh adanya Taman Teknologi Pertanian di Kelurahan tersebut yang dapat dijadikan penambahan pendapatan.

Kelurahan Banturung memiliki letak strategis yaitu berada pada jalur yang menghubungkan antara Ibukota Provinsi dan 5 Kabupaten lainnya di Kalimantan Tengah dan dekat dengan pusat perdagangan dan pusat pemerintahan Provinsi Kalimantan Tengah. Kondisi tersebut merupakan keunggulan bagi Kelurahan Banturung untuk lebih mampu memanfaatkan letak yang strategis guna mendorong pembangunan ekonominya yang berbasiskan agroindustri. Pada sisi lain, pembangunan ekonomi di Kelurahan Banturung masih terdapat masalah diantaranya penyebaran kawasan pertanian tidak merata walaupun kondisi wilayah sangat menunjang sehingga perkembangan antar wilayah kurang cepat. Luas lahan yang mendukung sektor pertanian cukup luas yaitu namun pemanfaatannya kurang maksimal. Hal ini didasari bahwa Taman Teknologi Pertanian yang berada di daerah tersebut seluas 1,7 ha dan pada Tahun 2016 terdapat penambahan seluas 30 ha. Pemanfaatan luas lahan untuk Taman Teknologi Pertanian yang dapat dijadikan sumber pendapatan berbasis pertanian belum maksimal.

Potensi sumber daya alam yang terdapat di wilayah Kelurahan Banturung mendukung untuk dikembangkannya Kelurahan Banturung sebagai kawasan agroindustri. Pengembangkan Kelurahan Banturung melalui optimalisasi sumber daya alam yang berada di wilayah tersebut perlu dilakukan yang dimulai dengan analisis kondisi wilayah, potensi unggulan wilayah, dan permasalahan yang ada di wilayah tersebut. Hasil analisis kondisi wilayah selanjutnya digunakan sebagai dasar pertimbangan dalam menemukan strategi pengembangan wilayah. Keterkaitan antara perkembangan kondisi sosial ekonomi masyarakatnya, potensi sumber daya alam, serta ketersediaan sarana dan prasarana wilayah juga perlu diperhatikan dalam mendukung perekonomian wilayah tersebut. Upaya pengembangan wilayah juga perlu memperhatikan sektor dan komoditas yang dapat tumbuh dan berkembang cepat di wilayah tersebut. Sektor dan komoditas tersebut haruslah yang merupakan sektor unggulan atau mempunyai prospek untuk dipasarkan ke luar wilayah dan dapat dikembangkan secara maksimal. Kelurahan Banturung sebagai penguatan sentra-sentra produksi pertanian yang berbasiskan kekuatan internal, diharapkan mampu berperan sebagai kawasan pertumbuhan ekonomi yang mempunyai daya kompetensi inter dan intra regional.

Penetapan suatu komoditas sebagai komoditas unggulan (basis) pada suatu daerah harus disesuaikan dengan potensi sumberdaya alam dan sumber daya manusia yang dimiliki oleh daerah itu sendiri. Komoditas yang dipilih sebagai komoditas unggulan daerah adalah komoditas yang memiliki produksi yang tinggi dan dapat memberikan nilai tambah sehingga berdampak positif bagi kesejahteraan masyarakat dalam meningkatkan ekonomi. Selain itu, pengidentifikasian dan penetapan komoditas unggulan pada suatu daerah juga harus mempertimbangkan kontribusi suatu komoditas terhadap pertumbuhan ekonomi dan aspek pemerataan pembangunan pada daerah itu sendiri (Syahroni, 2005).

Perencanaan pengembangan komoditas unggulan di Kelurahan Banturung tidak terlepas dari potensi sumber daya alam yang melekat pada daerah tersebut dan pemanfaatan sumber daya alam tersebut secara bijaksana, yaitu terarah, efisien, sistematik dan berkelanjutan. Daerah ini mempunyai potensi sumber daya alam dan lahan potensial untuk komoditi unggulannya yang bernilai komersial. Pengembangan wilayah tersebut perlu dilakukan agar dapat meningkatkan kapasitas produksi lokal dan nilai tambah melalui pelaksanaan pembangunan pertanian secara terpadu dan dalam rangka mempercepat pertumbuhan dan pengembangan wilayah berbasis kawasan.

Manik et al. (2013) menyatakan bahwa pengembangan kawasan agroindustri secara berkelanjutan membutuhkan strategi berupa pengembangan sub sistem agribisnis sesuai komoditas unggulan, arahan tata ruang kawasan, pengembangan sistem usaha tani, pengembangan infrastruktur pendukung agroindustri serta pengembangan sumber daya manusia. Penelitian yang dilakukan oleh Syafruddin et al. (2018) menjelaskan bahwa analisis kinerja komoditas unggulan memberikan dukungan dan dampak positif terhadap pengembangan produk hortikultura dengan nilai LQ > 1 yaitu markisa, kentang, tomat, wortel, kubis, sawi putih, dan pisang.

Berdasarkan latar belakang yang telah diuraikan maka untuk pengembangan komoditas unggulan diperlukan penelitan tentang strategi pengembangan komoditas unggulan secara menyeluruh, terintegrasi, dan berkelanjutan di Kelurahan Banturung Kecamatan Bukit Batu.

\section{METODOLOGI}

Penelitian dilaksanakan di Kelurahan Bantarung Kecamatan Bukit Batu Kota Palangka Raya Kalimantan Tengah. Penelitian ini dilaksanakan pada bulan April 2019 sampai April 2020.

Penelitian ini dilakukan melalui 2 (dua) tahapan analisis. Pertama, menentukan komoditas unggulan tanaman hortikultura di Kelurahan Banturung dengan Analisis LQ dan preferensi petani. Kedua, menentukan strategi pengembangan komoditas unggulan tanaman hortikultura di Kelurahan Banturung dengan Analisis SWOT.

Analisis SWOT dilakukan untuk mengidentifikasi secara sistematik antara kekuatan dan kelemahan dari faktor internal serta peluang dan ancaman dari faktor eksternal yang dihadapi, sehingga dapat dibuat suatu alternatif strategi. Analisis SWOT digunakan untuk mengetahui potensi Kelurahan Banturung melalui identifikasi faktor eksternal dan internal yang berpengaruh pada kriteria yang digunakan, serta mengetahui peluang dan kekuatan yang 
dimiliki untuk menentukan rencana serta mengatasi kelemahan dan ancaman dengan rencana perbaikan.

Teknik pengambilan data dalam penelitian ini terdiri dari observasi, wawancara,kuisioner,studi literatur dan dokumentasi. Data yang digunakan bersumber dari data primer dan data sekunder. Data primer diperoleh melalui observasi, wawancara, dan dokumentasi. Data sekunder adalah data yang dikumpulkan melalui studi pustaka dan data-data yang diperoleh dariinstansi yang berkaitan langsung dengan kegiatan pengembangan komoditas unggulan pertanian. Responden penelitian merupakan informan kunci yang berperan dalam pengembangan komoditas di Kelurahan Banturung. Responden untuk memperoleh informasi identifikasi komoditas unggulan adalah kelompok tani yang terdapat di Kelurahan Banturung yaitu Kelompok Tani Karya Muda (16 orang anggota) dan Jadi Mulya (25 orang anggota). Responden untuk analisis SWOT berasal dari instansi Dinas Ketahanan Pangan dan Pertanian Kota Palangka Raya, Balai Penyuluh Pertanian Tangkiling, Badan Pusat Statistik (BPS) Palangka Raya yang berjumlah 5 orang responden. Penentuan strategi pengembangan komoditas unggulan di Kelurahan Banturung dilakukan analisis SWOT (Strengths, Weakness, Opportunities, dan Threats).

\section{HASIL}

\subsection{Identifikasi Komoditas Unggulan di Kelurahan Banturung}

Penentuan komoditas unggul pada penelitian ini difokuskan pada komoditas tanaman hortikultura di Kelurahan Banturung Kecamatan Bukit Batu Kota Palangka Raya. Teknik analisa komoditas unggulan menggunakan analisa LQ dengan memanfaatkan data luas panen dan produksi di Kelurahan Banturung. Komoditas unggulan dipilih berdasarkan hasil perhitungan $L Q>1$, yang diindentifikasi sebagai komoditas basis.

Berdasarkan hasil perhitungan LQ, menunjukkan terdapat 8 (delapan) komoditas yang memiliki nilai LQ $>1$ dengan nilai tertinggi secara bertutut turut adalah buncis $(\mathrm{LQ}=8,26)$, kacang panjang $(\mathrm{LQ}=2,75)$, cabe rawit $(L Q=2,75)$, tomat $(L Q=2,75)$, cabe besar $(L Q=2,19)$, bawang merah $(\mathrm{LQ}=2,06)$, ketimun $(\mathrm{LQ}=2,06)$, dan terung $(\mathrm{LQ}=1,84)$. Sepuluh komoditas lainnya memiliki nilai $\mathrm{LQ}<1$ yaitu semangka $(\mathrm{LQ}=0,49)$, melon $(\mathrm{LQ}=0,38)$, bawang daun $(\mathrm{LQ}=0)$, kubis $(\mathrm{LQ}=0)$, kembang $\mathrm{kol}(\mathrm{LQ}=0)$, petsai/sawi $(\mathrm{LQ}=0)$, wortel $(\mathrm{LQ}=0)$, jamur $(\mathrm{LQ}=0)$, kangkung $(\mathrm{LQ}=0)$, dan bayam $(\mathrm{LQ}=0)$. Hasil perhitungan $L Q$ disajikan pada Tabel 1.

Hasil perhitungan nilai LQ>1 menggambarkan bahwa komoditas tersebut memiliki keunggulan komparatif yang hasilnya tidak hanya dapat memenuhi kebutuhan daerah yang bersangkutan tetapi dapat diekspor ke luar wilayah. Klasifikasi komoditas dengan LQ> 1 tergolong dalam sektor basis. Nilai $\mathrm{LQ}<1$ belum merupakan komoditas unggulan
Tabel 1. Nilai LQ komoditas tanaman hortikultura

\begin{tabular}{|c|c|c|}
\hline No & Jenis Komoditas & LQ \\
\hline 1 & Bawang Merah & 2,06 \\
\hline 2 & Bawang Daun & 0,00 \\
\hline 3 & Kubis & 0,00 \\
\hline 4 & Kembang Kol & 0,00 \\
\hline 5 & Petsai/Sawi & 0,00 \\
\hline 6 & Wortel & 0,00 \\
\hline 7 & Kacang Panjang & 2,75 \\
\hline 8 & Cabe Besar & 2,19 \\
\hline 9 & Cabe Rawit & 2,75 \\
\hline 10 & Jamur & 0,00 \\
\hline 11 & Tomat & 2,75 \\
\hline 12 & Terung & 1,84 \\
\hline 13 & Buncis & 8,26 \\
\hline 14 & Ketimun & 2,06 \\
\hline 15 & Kangkung & 0,00 \\
\hline 16 & Bayam & 0,00 \\
\hline 17 & Melon & 0,38 \\
\hline 18 & Semangka & 0,49 \\
\hline
\end{tabular}

Sumber: BPPPK (2018). Diolah.

dan tergolong dalam sektor non basis. Perhitungan nilai LQ komoditas tanaman hortikultura pada penelitian ini tidak ada hasil $L Q=1$ yang menunjukkan bahwa komoditas bersifat seimbang pada Kelurahan Banturung atau bermakna pada tingkat pemasaran hanya mampu melayani pasar wilayah setempat saja.

Komoditas unggulan di Kelurahan Banturung perlu diidentifikasi karena daerah ini mempunyai aktivitas pertanian yang aktif dan sebagai salah satu daerah yang ditetapkan sebagai daerah sentra pertanian. Hal ini didukung oleh Surat Keputusan Walikota Palangka Raya, berdasarkan Surat Keputusan Walikota Palangka Raya No 188.45/510/2015 tentang penetapan lokasi tanah kepada Dinas Pertanian, Perkebunan, Pelaksana Penyuluhan untuk kepentingan pembangunan Taman Teknologi Pertanian (Agro Technopark) dimana telah diputuskan bahwa TTP berada di Kelurahan Banturung Kecamatan Bukit Batu.

Syahroni (2005) menjelaskan bahwa penetapan suatu komoditas sebagai komoditas unggulan (basis) pada suatu daerah harus disesuaikan dengan potensi sumberdaya alam dan sumberdaya manusia yang dimiliki oleh daerah itu sendiri. Komoditas yang dipilih sebagai komoditas unggulan daerah adalah komoditas yang memiliki produksi yang tinggi dan dapat memberikan nilai tambah sehingga 
berdampak positif bagi kesejahteraan masyarakat dalam meningkatkan ekonomi. Selain itu, pengidentifikasian dan penetapan komoditas unggulan pada suatu daerah juga harus mempertimbangkan kontribusi suatu komoditas terhadap pertumbuhan ekonomi dan aspek pemerataan pembangunan pada daerah itu sendiri.

Komoditas buncis sangat unggul di Kelurahan Banturung dimana koefisien LQ 8,26. Faktor yang mendukung komoditas buncis ini yaitu lahannya cukup mendukung untuk penanaman buncis. Tanaman buncis merupakan sayuran buah yang termasuk ke dalam kelompok leguminosa. Budidaya buncis cocok dilakukan di semua dataran baik dataran tinggi, dataran menengah ataupun dataran rendah dengan kesesuaian di berbagai jenis tanah seperti tanah lempung, tanah liat berpasir, dan lainnya. Tanaman buncis membutuhkan sinar matahari penuh setiap harinya sehingga sangat efisien jika ditaman saat musim kemarau.

Kelurahan Banturung mempunyai jenis tanah Ketinggian Kelurahan Banturung Kecamatan Bukit Batu adalah 40-60 m dpl. Buncis mulai berbunga pada 40 hari setelah tanam. Pada umur 50 hari, buncis sudah bisa dipanen sehingga dengan resiko waktu yang tidak lama dapat mendukung pengembangan komoditas unggulan di Kelurahan Banturung. Komoditas unggulan terbesar setelah buncis adalah cabe rawit, cabe besar dan tomat. Ketiga komoditas tersebut mempunyai faktor pendukung yaitu kesesuaian dan kemudahan tanaman cabe dan tomat untuk dapat tumbuh, masyarakat di Kelurahan Banturung menjadikan komoditas cabe dan tomat sebagai kebutuhan sehari hari dan menjadi aktifitas menanam cabe dan tomat sepanjang waktu.

Hasil budidaya bawang merah di Kelurahan Banturung dapat mensuplai kebutuhan bawang merah di Kota Palangka Raya. Hal ini dapat dilihat bahwa nilai LQ bawang merah adalah 2,06. Bawang merah merupakan salah satu tanaman rempah yang sangat dibutuhkan oleh masyarakat sebagai bahan campuran penyedap makanan. Dukungan pemerintah sangat membantu pengembangan budidaya bawang merah yaitu melalui penyediaan benih bawang merah melalui optimalisasi produksi kelompok tani penangkar benih. Penyediaan benih tersebut sebagai salah satu upaya pemberdayaan kelompok tani untuk mengoptimalkan produksi benih bawang sebagai sumber penyediaan benih. Upaya ini dilakukan dengan melakukan penangkaran benih bawang merah sesuai kebutuhan benih Kelompok Tani, sehingga dapat terbentuk Kelompok Tani yang mampu memproduksi sendiri benih untuk pengembangan bawang merah di wilayahnya sendiri. Salah satu kelompok tani yang pada saat ini sedang mengembangkan bawang merah di wilayah Kelurahan Banturung adalah Kelompok Tani Karya Muda.

Pengembangan budidaya komoditas bawang merah di Kalimantan Tengah telah difokuskan di Kelurahan Banturung. Dukungan pengembangan komoditas bawang merah dari Pemerintah Kota Palangka Raya diimplementasikan melalui adanya Nota Kesepahaman
Nomor 02 tahun 2012 Tanggal 25 Juni 2012 antara Pemerintah Kota Palangka Raya dan Bank Indonesia Kalimantan Tengah tentang Program Penguatan Ketahanan Pangan Komoditas bawang merah. Program ini diarahkan pada upaya memproduksi bawang merah segar untuk kebutuhan konsumsi yang bisa langsung diserap oleh pasar lokal maupun nasional sehingga akan memberikan kontribusi pada penekanan laju inflasi serta pemenuhan kebutuhan benih secara mandiri tanpa harus bergantung pada daerah produsen di luar Kalimantan. Pelaku usahatani dalam bentuk kelompok tani menyambut baik program tersebut dan menjadikan program tersebut sebagai salah satu peluang untuk meningkatkan hasil komoditas bawang merah yang berimplikasi pada pendapatannya.

Komoditas yang memiliki nilai $\mathrm{LQ}<1$ antara lain wortel. Pada tahun 2015, petani di Banturung telah melakukan percobaan penanaman wortel di daerah Banturung yang memiliki ketinggian kurang dari $40 \mathrm{~m}$ dpl dan suhu ratarata $280 C$. Lahan yang digunakan pengkajian wortel adalah lahan yang tersusun atas tanah mineral bertekstur lempung liat berpasir di Kelurahan Banturung. Kondisi lahan dan lingkungan di Kelurahan Banturung belum optimal bagi kesesuaian tanaman wortel untuk tumbuh, dimana sentra tanaman wortel di Indonesia umumnya terletak di dataran tinggi sekitar $1.000 \mathrm{~m}$ dpl dengan suhu lebih kurang $21^{\circ} \mathrm{C}$.

Komoditas unggulan di Kelurahan Banturung dapat dikembangkan dengan memperhatikan nilai LQ. Komoditas yang mempunyai nilai $L Q>1$ dapat diklasifikasikan ke dalam sektor basis atau unggulan. Hendayana (2003) menyatakan bahwa teknik LQ merupakan salah satu pendekatan yang umum digunakan dalam pendekatan model ekonomi basis sebagai langkah awal untuk memahami sektor kegiatan yang menjadi pemacu pertumbuhan.

Analisis LQ telah digunakan oleh beberapa penelitian terdahulu untuk menganalisis komoditas unggulan. Penelitian Syafruddin et al. (2018) bertujuan untuk menetapkan alternatif lokasi berbasis komoditas tanaman hortikultura unggulan di Kecamatan Tinggimoncong Kabupaten Gowa. Hasil penelitian tersebut menunjukkan bahwa komoditas unggulan hortikultura berdasarkan analisis LQ di Kecamatan Tinggimoncong adalah yaitu Markisa $(L Q=1,03)$, Kentang $(L Q=4,01)$, Tomat $(L Q=3)$, Wortel $(L Q=1,51)$, Kubis $(L Q=1,30)$, Sawi Putih $(L Q=1,04)$ dan Pisang $(L Q=1,1)$.

Arya et al. (2019) menggunakan teknik LQ untuk mengidentifikasi komoditas unggulan sektor pertanian di beberapa Kecamatan Kota Pare Pare. Sub sektor hortikultura terdapat komoditas unggulan yang terdiri dari Kecamatan Bacukiki Barat dengan komoditas cabe, terong, tomat, dan jambu air dan Soreang terdiri dari komoditas kacang tanah dan kangkung. Cipta et al. (2017) menyatakan bahwa identifikasi komoditas unggulan perlu dilakukan untuk mendorong keberlanjutan komoditas unggulan daerah yang dapat mendukung pengembangan 
suatu kawasan pertanian. Pendekatan yang dapat dilakukan untuk penentuan komoditas unggulan antara lain pendekatan agroekosistem, pendekatan kesinambungan, pendekatan partisipatif dan pendekatan terpadu.

\subsection{Analisis SWOT}

Strategi pengembangan komoditas unggulan dianalisis berdasarkan hasil analisis faktor eksternal dan internal berupa kekuatan, kelemahan, peluang dan ancaman dalam pengembangan komoditas unggulan. Perumusan alternatif strategi meliputi dua tahapan, yaitu tahap input (input stage) dan tahan pencocokan (matching stage). Tahap input merupakan tahap pengelompokan hasil identifikasi serta menyimpulkan informasi dasar yang diperlukan untuk merumuskan strategi dengan menggunakan matriks IFE (Internal Factor Evaluation) dan EFE (External Factor Evaluation). Tahap kedua yaitu tahap pencocokan merupakan tahap perumusan strategi menggunakan analisis matriks IE (Internal-External) dan SWOT.

Tahapan input merupakan tahapan pertama yang dilakukan sebelum melanjutkan ke langkah selanjutnya dalam tahap formulasi strategi. Pada tahap ini dilakukan pengelompokan hasil identifikasi faktor-faktor lingkungan internal dan eksternal pengelolaan komoditas tanaman pangan ke dalam matriks IFE dan EFE.

Pembobotan faktor internal merupakan suatu upaya untuk membandingkan setiap faktor internal yang mempengaruhi pengembangan komoditas tanaman pangan. Hasil penilaian bobot dan rating masing-masing responden kemudian dibuat dalam bentuk matriks IFE dari keseluruhan responden. Matriks IFE menjabarkan faktorfaktor strategis internal dalam kategori kekuatan dan kelemahan pengembangan komoditas tanaman pangan. Hasil analisis matriks IFE menggambarkan seberapa besar pengaruh faktor-faktor strategis internal terhadap pengembangan komoditas.Data mengenai faktor kekuatan dan kelemahan disajikan dalam Matriks IFE pada Tabel 2.

Total nilai pengaruh faktor internal secara keseluruhan adalah 1,5020. Sedangkan faktor strategis internal yang menjadi kelemahan utama dalam pengembangan tanaman pangan adalah pendanaan yang masih kurang optimal dalam mendukung petani mengembangkan tanaman pangan yang memiliki nilai pengaruh yaitu sebesar 0,4000. Nilai kecenderungan terhadap faktor internal bernilai negatif yaitu $-0,0684$.

Matriks EFE menjabarkan faktor-faktor strategis eksternal berupa peluang serta ancaman bagi pengembangan komoditas unggulan tanaman pangan. Hasil analisis EFE menggambarkan sejauh mana faktorfaktor strategis eksternal berpengaruh terhadap pengembangan komoditas. Perolehan nilai bobot dan rating didapatkan berdasarkan dari hasil wawancara dengan lima orang informan. Penilaian bobot merupakan perhitungan rata-rata penilaian responden terhadap

Tabel 2. Matriks Internal Factor Evaluation (IFE)

\begin{tabular}{|c|c|c|c|c|}
\hline & Faktor Strategi & Rata-rata Bobot & Rata-rata Rating & Nilai Pengaruh \\
\hline \multicolumn{5}{|c|}{ Kekuatan (Strengths) } \\
\hline 1 & Sarana produksi & 0,110 & 3,0 & 0,3300 \\
\hline 2 & Sumberdaya manusia & 0,130 & 3,2 & 0,4160 \\
\hline 3 & Kesesuaian lahan & 0,080 & 2,2 & 0,1760 \\
\hline 4 & Kelembagaan & 0,080 & 2,6 & 0,2080 \\
\hline 5 & Kinerja usaha & 0,122 & 2,0 & 0,2440 \\
\hline \multirow[t]{3}{*}{6} & Kualitas produksi & 0,064 & 2,0 & 0,1280 \\
\hline & Total & 0,586 & & 1,5020 \\
\hline & \multicolumn{4}{|l|}{ Kelemahan (Weaknesses) } \\
\hline 1 & Data informasi & 0,080 & 3,2 & 0,2560 \\
\hline 2 & Pendanaan & 0,100 & 4,0 & 0,4000 \\
\hline 3 & Proses produksi & 0,060 & 4,0 & 0,2400 \\
\hline 4 & Pengolahan & 0,070 & 4,0 & 0,2800 \\
\hline 5 & Pemasaran & 0,050 & 4,0 & 0,2000 \\
\hline 6 & Sosialisasi & 0,054 & 3,6 & 0,1944 \\
\hline & Total & 0,414 & & 1,5544 \\
\hline \multicolumn{2}{|r|}{ Kecenderungan Terhadap Faktor Internal } & 1,000 & & $-0,0684$ \\
\hline
\end{tabular}


seluruh faktor-faktor strategis eksternal. Rating merupakan penilaian responden dalam pengukuran berapa besar pengaruh faktor tersebut terhadap pengembangan komoditas. Matriks EFE menyajikan hasil analisis faktorfaktor strategis eksternal, dimana terbagi dalam golongan empat peluang dan enam ancaman lingkungan eksternal yang dijabarkan dalam matriks EFE pada Tabel 3.

Salah satu faktor peluang dengan nilai pengaruh terbesar $(0,3672)$ adalah potensi permintaan pasar. Peluang tersebut merupakan faktor penting dalam menunjang keberhasilan pengelolaan dan pengembangan komoditas tanaman hortikultura karena selama ini pemerintah telah menyediakan sarana dan prasarana, sekaligus pendampingan terhadap petani dalam meningkatkan hasil panen tanaman hortikultura Dukungan pemerintah juga telah diwujudkan dalam pemberian bibit tanaman dan pupuk organik maupun anorganik juga sarana dan prasarana lainnya. Kualitas produksi dan sensivitas konsumen di kelurahan Banturung menjadi ancaman tersendiri yang mempengaruhi pengembangan komoditas tanaman hortikultura jika tidak diikuti dengan adanya upaya peningkatan mutu yang baik terhadap semua hasil produkdi tanaman hortikultura.

Berdasarkan faktor-faktor internal dan eksternal yang telah diidentifikasi, pengembangan komoditas tanaman pangan berada di kuadran 3, di mana peluang yang dimiliki tinggi akan tetapi terdapat kelemahan internal yang juga tinggi. Strategi yang sebaiknya diterapkan pada kondisi kuadran tiga yaitu trategi turn around dimana masalah-masalah internal diminimalkan sehingga dapat memanfaatkan peluang-peluang yang ada (Rangkuti, 2009). Gambar 1 menunjukkan posisi mendukung strategi konservatif yang menggunakan peluang yang ada untuk mengatasi kelemahan.

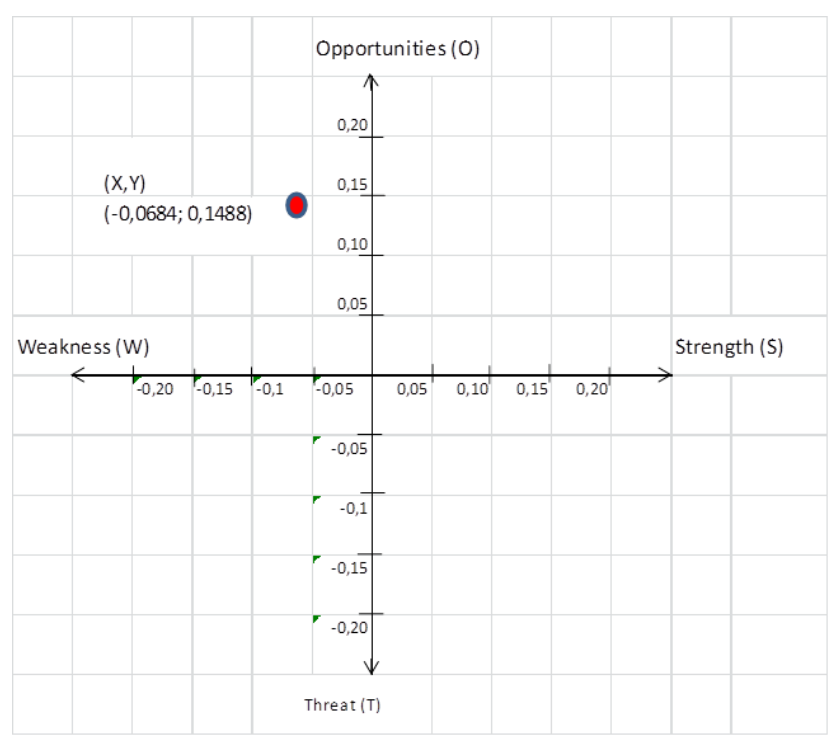

Gambar 1. Kedudukan strategi pengembangan tanaman pangan di Kelurahan Banturung Kecamatan Bukit Batu

\section{PEMBAHASAN}

Strategi alternatif pengembangan komoditas tanaman hortikultura yang memungkinkan untuk diimplementasikan berdasarkan posisi kuadran III adalah sebagai berikut:

Tabel 3. Matriks Eksternal Factor Evaluation (EFE)

\begin{tabular}{|c|c|c|c|c|}
\hline & Faktor Strategi & Rata-rata Bobot & Rata-rata Rating & Nilai Pengaruh \\
\hline \multicolumn{5}{|c|}{ Peluang (Opportunity) } \\
\hline 1 & Kerjasama & 0,066 & 3,8 & 0,2508 \\
\hline 2 & Dukungan pemerintah & 0,070 & 3,8 & 0,2660 \\
\hline 3 & Sumber Daya Alam & 0,056 & 3,6 & 0,2016 \\
\hline 4 & Potensi Permintaan Pasar & 0,102 & 3,6 & 0,3672 \\
\hline 5 & Peluang Pengembangan Investasi & 0,070 & 2,0 & 0,1400 \\
\hline 6 & Daya dukung infrastruktur & 0,072 & 3,6 & 0,2592 \\
\hline & Total & 0,436 & & 1,4848 \\
\hline \multicolumn{5}{|c|}{ Ancaman (Threat) } \\
\hline 1 & Konversi Lahan & 0,072 & 1,2 & 0,0864 \\
\hline 2 & Sensivitas Konsumen & 0,108 & 3,0 & 0,3240 \\
\hline 3 & Koordinasi & 0,092 & 2,0 & 0,1840 \\
\hline 4 & Topografi dan Luas & 0,062 & 1,8 & 0,1116 \\
\hline 5 & Aksesbilitas & 0,060 & 1,6 & 0,0960 \\
\hline 6 & Sosial Ekonomi & 0,078 & 2,6 & 0,2028 \\
\hline \multirow[t]{3}{*}{7} & Bencana Alam & 0,092 & 3,6 & 0,3312 \\
\hline & Total & 0,564 & & 1,3360 \\
\hline & Kecenderungan terhadap faktor eksternal & 1,00 & & 0,1488 \\
\hline
\end{tabular}


1. Peningkatan kerjasama/kemitraan lembaga tani dengan pihak swasta atau pemerintah.

2. Peningkatan daya dukung infrastruktur, sarana dan prasarana untuk mendukung proses pemasaran hasil produksi.

3. Pengoptimalan bantuan permodalan dari pemerintah sebagai stimulan untuk inovasi pengolahan, pemasaran, dan sosialisasi hasil produksi.

4. Penyediaan data informasi untuk mendukung permintaan pemasaran.

Berdasarkan rumusan strategi tersebut diketahui bahwa diperlukan kerjasama yang dapat mendukung pengembangan hasil tanaman hortikultura. Kerjasama yang terjalin diharapkan dapat meningkatkan nilai tambah kelompok tani melalui inovasi pengolahan hasil tanam. Seran dan Taena (2019) menunjukkan bahwa strategi untuk mengatasi kelemahan dan memanfaatkan peluang adalah melalui perluasan kerjasama dengan sektor swasta dan pemerintah dalam mengembangkan tanaman hortikultura khususnya bawang merah.

Proses pemasaran hasil produksi sangat diperlukan untuk meningkatkan nilai kesejahteraan petani yang didapat dari proses distribusi pemasaran hasil. Daya dukung insfrastruktur sangat diperlukan agar proses distribusi hasil dapat berjalan lancar dan baik. Hasil penelitian Kartikawati dan Makmur (2015) menunjukkan bahwa peningkatan kualitas dan kuantitas hasil produksi tanaman pertanian harus diikuti dengan peningkatan daya dukung kebijakan pemerintah terkait dengan perencanaan pemasaran. Salah satu kendala pemasaran adalah lemahnya akses pasar dan akses lembaga keuangan karena tidak tersedianya infrastruktur penunjang pemasaran hingga ke pelosok desa.

Teknologi informasi dan komunikasi berperan penting dalam pemasaran hasil produksi tanaman hortikultura. Menurut Ismet dan Indiarto (2006), teknologi informasi mampu memberikan informasi yang dibutuhkan pelaku pasar seperti harga komoditi, data produk dan kualitas, kondisi cuaca, ketersediaan akses pasar, kredit pertanian hingga promosi pasar. Beberapa permasalahan yang terkait dengan pemanfaatan teknologi informasi di tingkat petani adalah infrastruktur telekomunikasi yang lemah, rendahnya kualitas tenaga ahli bidang teknologi informasi, kekuatiran penggunaan teknologi baru, dan proses pemasaran yang bersifat konservatif bagi petani.

Alokasi pendanaan untuk mendukung pemanfaatan teknologi informasi bagi pengembangan komoditas unggulan tanaman hortikultura sangat dibutuhkan. Peran pemerintah juga sangat diperlukan untuk memperkuat jaringan informasi pasar seperti pemasaran dan produksi. Istiqamah dan Novita (2017) dalam hasil penelitiannya menunjukkan bahwa peran pemerintah dalam bentuk finansial sangat diharapkan dalam rangka mendorong dan mempertahankan agar beberapa komoditas yang menjadi sektor basis tetap menjadi unggulan. Pemerintah harus mendorong peningkatan produksi komoditas ini beserta turunan produknya agar memberikan nilai tambah ekonomi yang tinggi, sehingga petani tetap menjaga luas tanam dari kegiatan pertanian.

Hasil penelitian dalam penetapan komoditas unggulan di Kelurahan Banturung diharapkan mempunyai keberlanjutan yang diterapkan dalam bentuk program dari pemerintah. Menurut Bachrein (2003), penetapan komoditas unggulan dapat dijadikan dasar dalam penyusunan program yang dilakukan oleh penentu kebijakan dan berkaitan dengan keberhasilan pembangunan suatu wilayah. Perencanaan program sangat diperlukan sebagai arahan kebijakan pengembangan komoditas unggulan. Dalam membuat perencanaan program tersebut diharapkan memperhatikan aspirasi dan isu yang berkembang di masyarakat. Hal ini dikarenakan dalam pelaksana program yang ditetapkan pemerintah adalah masyarakat sebagai pelaku. Selain itu kriteria dalam perencanaan program didasarkan pada kriteria ekologi, ekonomi dan sosial.

Kriteria ekologi mengupayakan agar pengembangan komoditas unggulan memperhatikan keberlanjutan sumber daya alam yang ada di Kelurahan Banturung. Hal yang terkait dengan ekologi antara lain kesesuaian lahan dan kelestarian lingkungan dalam proses budidaya tanaman. Kesesuaian lahan akan berpengaruh terhadap produksi tanaman hortikultura yang disesuaikan jenisnya. Kriteria ekonomi berkaitan dengan analisis manfaat yang diperoleh dalam pengembangan komoditas unggulan. Keuntungan finansial dalam usahatani meliputi peluang pasar dan peluang peningkatan pendapatan.

Kriteria sosial dapat didasarkan pada kelembagaan dan peraturan yang dapat mendukung dan penentu keberhasilan pengembangan komoditas unggulan. Pada ranah kelembagaan dapat meliputi kelembagaan eksisting kelompok tani, peraturan pengelolaan, dan pelaksanaan monitoring. Peraturan pengelolaan dapat didukung dengan adanya koperasi di kelompok tani Kelurahan Banturung. Sumberdaya manusia dalam hal ini petani sebagai pelaku pengembangan komoditas unggulan tanaman hortikultura juga memerlukan penguasaan teknologi budidaya tanaman dan ketersediaan sarana dan prasarana produksi.

Arahan kebijakan pengembangan komoditas unggulan di Kelurahan Banturung didukung oleh dua kebijakan yang dilakukan pemerintah. Kebijakan pemerintah yang pertama dituangkan pada Peraturan Daerah Kota Palangka Raya Nomor 07 Tahun 2001 tentang Rencana Tata Ruang Wilayah Kota Palangka Raya. Analisis terhadap Rencana Tata Ruang dan Wilayah berkaitan dengan pengembangan wilayah agroindustri disebutkan bahwa ditetapkan wilayah pengembangan di Kecamatan Bukit Batu. Kebijakan kedua dari pemerintah dalam mendukung pengembangan komoditas unggulan tanaman hortikultura di Kelurahan Banturung adalah berdasarkan Surat Keputusan Walikota Palangka Raya yang menetapkan Taman Teknologi Pertanian (Agro Technopark) berada di Kelurahan Banturung Kecamatan Bukit Batu. Pengembangan 
komoditas unggulan dapat memantapkan ketahanan pangan dalam ketersediaan dan distribusi pangan.

Arah kebijakan yang dapat dilakukan pemerintah dalam pengembangan komoditas unggulan tanaman hotikultura di Kelurahan Banturung adalah 1) pendampingan petani melalui edukasi untuk meningkatkan kualitas dan kualitas produksi, 2) pembinaan pengolahan hasil pertanian dengan teknologi tepat guna di kelompok tani, 3) rehabilitasi dan penambahan infrastruktur, sarana dan prasarana pertanian, 4) pembinaan inovasi pemasaran, 5) penguatan kelembagaan kelompok tani, dan 6) perluasan kerjasama/kemitraan antara lembaga tani dengan pihak swasta/pemerintah.

Kelompok tani berperan penting bagi petani dalam pengembangan komoditas unggulan tanaman hortikultura. Segala bentuk aktivitas pertanian dan permasalahannya dalam usahatani dapat didiskusikan secara bersama untuk solusi permasalahan yang ada, misalnya, pemenuhan sarana produksi pertanian, teknis produksi dan pemasaran hasil. Kemandirian dan kemampuan petani dalam pemasaran juga perlu ditingkatkan melalui inovasi pemasaran berbasis teknologi informasi dan komunikasi. Hal ini dapat menghindari ketergantungan petani kepada tengkulak yang pada umumnya harga relatif lebih rendah dibandingkan petani menjual ke konsumen langsung.

Pemasaran melalui aplikasi teknologi dapat memenuhi kebutuhan konsumen yang pada masa sekarang semua kalangan masyarakat ingin melakukan berbagai aktivitas pembelian dengan praktis, mudah, cepat, dan aman. Layanan aplikasi tertentu dapat mengembangkan marketplace hasil pertanian sehingga sangat membantu para petani, terutama untuk meningkatkan penjualan hasil pertaniannya.

Pembangunan pertanian tidak terlepas dari pengembangan kawasan yang menempatkan pertanian sebagai penggerak perekonomian. Konsep pertanian yang berkelanjutan dapat diwujudkan dengan perencanaan wilayah yang berbasiskan sumberdaya alam yang ada di suatu wilayah tertentu. Penetapan komoditas unggulan pertanian perlu dilakukan dengan memperhatikan potensi yang dimiliki sebagai langkah awalnya. Faktor yang mempengaruhi pengembangan komoditas unggulan di Kelurahan Banturung terdiri dari faktor internal dan eksternal, sehingga diperlukan strategi pengembangan komoditas unggulan. Strategi yang diperoleh berdasarkan analisis SWOT diharapkan dapat dijadikan dasar untuk menentukan arah kebijakan bagi stakeholder atau pengambil keputusan.

\section{KESIMPULAN}

Berdasarkan hasil analisis data penelitian tentang komoditas unggulan di Kelurahan Banturung dan strategi pengembangan komoditas unggulan, maka kesimpulan penelitian ini adalah sebagai berikut:
1. Komoditas unggulan merupakan komoditas andlaan yang memiliki posisi strategis untuk dikembangkan di suatu wilayah dan mampu bersaing secara berkelanjutan. Penetapan komoditas unggulan dapat didasarkan pada nilai $L Q>1$ dan memerlukan sumbangsih pikiran dari masyarakat. Preferensi petani sebagai pelaku usahatani perlu dilakukan sebagai respon pemikiran petani terhadap kesesuaian komoditas unggulan yang dihasilkan. Komoditas unggulan dalam mendukung pengembangan kawasan di Kelurahan Banturung Kecamatan Bukit Batu berdasarkan nilai $\mathrm{LQ}$ dan $\mathrm{B} / \mathrm{C}$ ratio $>1$ serta preferensi petani adalah buncis $(\mathrm{LQ}=8,26)$, kacang panjang $(\mathrm{LQ}=2,75)$, bawang merah $(\mathrm{LQ}=2,06)$, dan terung $(\mathrm{LQ}=1,84)$.

2. Pemerintah Kota Palangka Raya pada dasarnya telah membuat kebijakan yang mendukung pengembangan Kelurahan Banturung dengan ditetapkannya Kelurahan Banturung sebagai lokasi Taman Teknologi Pertanian pada tahun 2015 dan Rencana Tata Ruang dan Wilayah Kota Palangka Raya tahun 2001 bahwa Kecamatan Bukit Batu sebagai wilayah pengembangan untuk agroindustri. Pengembangan wilayah salah satunya didukung dengan adanya penetapan komoditas unggulan di Kelurahan Banturung Kecamatan Bukit Batu. Strategi yang dapat dilakukan untuk pengembangan komoditas unggulan di Kelurahan banturung adalah 1) peningkatan kerjasama/kemitraan lembaga tani dengan pihak swasta atau pemerintah, 2) peningkatan daya dukung infrastruktur, sarana dan prasarana, 3) pengoptimalan bantuan permodalan dari pemerintah sebagai stimulan untuk inovasi pengolahan, pemasaran, dan sosialisasi hasil produksi, 4) penyediaan data informasi untuk mendukung permintaan pemasaran.

\section{DAFTAR PUSTAKA}

Arya, A., Zulkifli, Z. and Nurhapsa, N., 2019. Kajian Potensi Wilayah Komoditas Unggulan Sektor Pertanian Kota Parepare. Jurnal Galung Tropika, 8(1), 49-63.

Bachrein, S. 2003. Penetapan Komoditas Unggulan Propinsi. BP2TP Working Paper. Bogor(ID). Balai Pengkajian dan Pengembangan Teknologi Pertanian.

[BPPPK] Balai Penyuluhan Pertanian, Perikanan, dan Kehutanan. 2018. Kecamatan Bukit Batu.

[BPS] Badan Pusat Statistik. 2018. Palangka Raya Dalam Angka. BPS Kota Palangka Raya

Cipta, S.W., Sitorus, S.R. and Lubis, D.P., 2017. Pengembangan Komoditas Unggulan Di Wilayah Pengembangan Tumpang, Kabupaten Malang. Jurnal Kawistara, 7(2), 121-133.

Hendayana, R., 2003. Aplikasi metode Location Quotient (LQ) dalam penentuan komoditas unggulan nasional. Informatika Pertanian, 12(1), 658-675.

Ismet, M. and Indiarto, A.D., 2006. Pemanfaatan Teknologi 
Informasi Dalam Pemasaran Produk Pangan dan Pertanian di Asia. Jurnal Pangan, 15(1), 15-20.

Istiqamah, N. and Novita, U.D., 2017. Kajian Pengembangan Komoditas Unggulan Buah-Buahan di Kabupaten Sambas. Jurnal Manajemen Motivasi, 13(2), 936-946.

Kartikawati, M.T.D. and Makmur, M., 2015. Perencanaan Program Peningkatan Pemasaran Hasil Produksi Pertanian/Perkebunan di Kota Batu. Reformasi: Jurnal Ilmiah Ilmu Sosial dan Ilmu Politik, 5(1), 136-148.

Manik, T.R., Adrianto, D.W. and Subagiyo, A., 2013. Kajian Pengembangan Kawasan Agropolitan Seroja Kabupaten Lumajang. Jurnal Tata Kota dan Daerah, 5(1), 65-76.

Rangkuti, F., 2009. Analisis SWOT: Teknik Membedah Kasus Bisnis. Penerbit PT Gramedia Pustaka Utama, Jakarta.

Seran, A. and Taena, W., 2019. Tingkat Penerapan
Teknologi Pertanian dan Strategi Pengembangan Budidaya Bawang Merah (Allium cepa. L) di Desa Tes Kecamatan Bikomi Utara Kabupaten Timor Tengah Utara. AGRIMOR, 4(3), 29-33.

Syafruddin, R.F., Sari, D.P. and Kadir, M., 2018. Penentuan Komoditas Unggulan dan Struktur Komoditas Hortikultura di Kecamatan Tinggimoncong Kabupaten Gowa Berdasarkan Location Quotient (LQ) dan Klassen Typology (KT). Jurnal Galung Tropika, 7(1), 22-32.

Syahroni, M. 2005. Analisis Strategi Pengembangan Komoditas Unggulan Agribisnis di Kabupaten Dompu Provinsi Nusa Tenggara Barat. Tesis. Program Pasca Sarjana Manajemen dan Bisnis IPB, Bogor.

Walikota Palangka Raya. 2001. Peraturan Daerah Kota Palangka Raya. Tentang Rencana Tata Ruang Wilayah Kota Palangka Raya. 